\title{
En personlig betraktelse om vård och omsorg
}

\author{
ROSMARI ELIASSON-LAPPALAINEN
}

Under de många år jag som forskare studerat utvecklingstendenser inom offentlig vård och omsorg har jag sett besparingsiverns härjningar, omprioriteringar och inte minst nya ideologier och organisationsformer som tycks syfta till att förhindra mänskliga, personliga relationer och att kväsa individen och det individuella - både hos den som ger och får hjälp. Jerzy Einhorn har i boken Det är människor det handlar om (1998) riktat liknande kritik mot en utarmning av den palliativa vården, den som förunnas människor i livets slutskede.

Så hamnade vi själva, min man Pauli och jag, i dödens väntrum. Ofrivilligt - med "hull och hår" och dygnet runt - fann jag mig inkastad i mitt eget forskningsfält: vårdens och omsorgens vardag. Jag var inte längre den deltagande observatör som jag har viss vana vid att vara, utan alltigenom deltagare. Och fick i denna situation erfara en kvalificerad vård $i$ hemmet vars professionella kompetens gick hand $i$ hand med ett aldrig sinande personligt engagemang och en uppfinningsrik omsorg av alla de slag.

Rosmari Eliasson-Lappalainen, professor emerita i socialt arbete, Lunds universitet
Som omsorgsforskare tycker jag att det närmast är min skyldighet att försöka beskriva detta fenomen. Det ligger i vårt kritiska mandat som forskare att synliggöra orättfärdigheter, brister och begränsningar i den verklighet vi studerar och att efter bästa förmåga söka förklaringar. Detsamma bör rimligtvis gälla om vi råkar på de riktigt goda exemplen, där allting tycks fungera på det mest önskvärda sätt. I vår mångåriga forskning med fokus på hemtjänsten till gamla har vi förundrats över att det ofta ges en högst anständig hjälp, trots omöjliga villkor och förödande organiseringsprinciper.

I denna text vill jag ge några glimtar av mina personliga erfarenheter av en vårdform där organiseringen av arbetet framstår som ett ytterst målrationellt ideal i verksamheter vars syfte är att ge god omsorg. Att utgå från det självupplevda kan vara en förbryllande ansats i en vetenskaplig tidskrift. Mitt motiv är att jag tycker att min berättelse passar som hand i handske i de slutsatser som ihärdigt och samstämmigt dragits inom den ganska så omfattande äldreomsorgsforskning som engagerat mig och många andra forskare under ett kvarts sekel. Och: de grundläggande tanke- och 
organiseringsstrukturerna för en omsorg värd namnet torde vara desamma antingen det handlar om människor som drabbats av en dödlig sjukdom eller av åldrandets skröplighet.

\section{En kort tillbakablick på omsorgsforskningen}

När jag tidigt 1980-tal beträdde forskningsfältet "äldreomsorg" var det för mig ett fullständigt okänt landskap, såsom välfärdssektor och vardagsverklighet. Äldreomsorgen var redan då en stor del av välfärdsapparaten och den nordiska välfärdsstatsforskningen var omfattande och internationellt framstående. Men i den etablerade samhällsvetenskapliga forskningen fanns vid det laget inte mycket att hämta om äldreomsorgen eller de andra delar av välfärdsstaten som i praktiken vilade huvudsakligen på kvinnors axlar och/eller avlastade dem en del av den oavlönade omsorgen om barn och gamla. ${ }^{1}$ Som Karin Widerberg (1981) skrev i en polemisk artikel: "I de vetenskapliga teorierna är kvin-

1 Så småningom kom kvinnoforskare in på arenan, intresserade sig för omsorgsarbetet och dess samhälleliga funktion. Kvinnoforskare kom att mynta begrepp som den sociala servicestaten, omsorgsstaten, kvinnornas välfärdsstat (se t ex Leira 1992, Anttonen 1998). Idag finns det en omfattande internationell diskurs om omsorg som begrepp, som oavlönat och avlönat arbete, som välfärdsdimension, etik och moral. Men i våra tidiga inventeringar av befintlig forskning fann vi endast ett fătal arbeten som diskuterade omsorg som (kvinno-)arbete, samtliga signerade av den norska sociologen Kari Wærness (1980, 1982, 1984). nors situation och villkor ännu osynligare än i 'verkligheten'." (jfr Eliasson-Lappalainen 2007).

Jag hade i uppdrag att utforma ett forskningsprogram om äldreomsorg. Programmet kom att heta Äldreomsorgens vardag och villkor och har fortlevt i lite olika skepnader (se t ex Eliasson 1987/1995 och Eliasson-Lappalainen \& Szebehely 1999). ${ }^{2}$ I upptakten hämtade vi inspiration ur vad som då betecknades "kvinnoperspektiv", men också av sådana detaljerade beskrivningar och analyser av (det manliga) lönearbetets vardag och dess organisering, som vi fann hos Harry Braverman (1977) (jfr Eliasson-Lappalainen \& Szebehely 2008).

För några år sedan genomförde vi en omfattande inventering av befintlig forskning om äldreomsorgen i de nordiska länderna (Szebehely, red. 2005). På min lott föll att tillsammans med en norsk och en finsk forskare göra en genomgång av samtliga nordiska doktorsavhandlingar om äldreomsorg inom samhällsvetenskap och humaniora under perioden 1995-2004 (EliassonLappalainen, Wærness \& Tedre 2005). Särskilt den svenska produktionen av avhandlingar hade varit omfattande, för att inte säga explosionsartad, sett mot bakgrund av att det inte fanns en enda samhällsveten-

2 Marta Szebehelys avhandling Vardagens organisering (1995) realiserade i en empirisk studie i hög grad programmets intentioner. Bland de gemensamma publikationer som kommit till inom programmets ramar kan nämnas antologierna Egenheter och Allmänheter (Eliasson, red. 1992), Omsorgens skiftningar (Eliasson, red. 1996), Vad förgår och vad består (EliassonLappalainen \& Szebehely, red. 1998) och Hemhjälp iNorden (Szebehely, red. 2003). 
skaplig avhandling om äldreomsorg när vi själva (i motvind) påbörjade forskning inom detta fält. Ett par decennier senare hade jag att gå igenom ett 40-tal svenska doktorsavhandlingar och jag citerar lite ur min sammanfattning av den genomgången:

Om vi ser enbart till den forskning som avsatt sig $i$ akademiska avhandlingar finns det idag en omfattande - empiriskt grundad och vetenskapligt prövad - kunskap om äldreomsorgen som praxisfält.

Den forskning som arbetat ur ett "bottomup" perspektiv, haft vardagen i centrum och strävat efter att utveckla empirinära begrepp och teoretiska förståelseramar är mycket samstämmig $i$ sina slutsatser. Kärnan däri kan nog sammanfattas som att omsorg kräver ett individ- och situationsbaserat omdöme och arbetsvillkor som ger utrymme och stöd för utveckling av sådan kompetens.

Så länge "god omsorg" är det välfärdspolitiska mål som styr så är det således logiskt och förnuftigt att ett stort planerings- och beslutsansvar är delegerat till de som utför arbetet ( $j$ fr Vabø 2004). En sådan yrkesautonomi har faktiskt hemhjälpare i Norden länge haft. Det fungerade - och det är idag vetenskapligt belagt att detta är en förnuftig ordning, sett utifrån konsekvenserna både för de som ger och mottar hjälp. (a a, s. 360)

Men det är andra logiker som har styrt över äldreomsorgens organisering under många år. I stället för att återigen formulera och argumentera för slutsatser som grundats både på omfattande empiriska material och teoretiska och filosofiska diskurser om omsorg prövar jag en ny infallsvinkel: den personligt upplevda. ${ }^{3}$

\section{Anteckningar om kärleken och döden, vården och omsorgen}

\section{Bakgrundsteckning}

Vi möttes sommaren 1993, Pauli och jag. Vi var båda kring 55. Vi gifte oss 17 maj 1996. Glada som barn över att ha hittat hem efter ödsliga år, och omåttligt stolta över vårt mod att våga lita på kärleken. Vi fick lite mer än två år tillsammans, i den tryggheten.

Den diagnos Pauli fick innan vi varit gifta ett år var Mesoteliom - en ovanlig form av lungsäckstumör, elakartad och obotlig. Enda kända orsak: asbestsarbete. Lungläkaren sa rakt på sak: "Vi kan inget göra. Vi har inte räddat någon." Cancern lägger sig som ett hårt pansar på insidan av lungsäcken, försvårar andningen allt mer, äter upp vävnaderna på sin sida av bröstkorgen (i detta fall den högra) och slutar obönhörligen med döden, med stor sannolikhet inom ett år efter diagnos. Vi fick ett och ett halvt år.

Ett drygt år efter beskedet hade vi, närmast i panik, flyttat från Lund till vårt lantställe Boahult. Paulis andningssvårigheter hade förvandlat de två trapporna i Lund till en bergsbestigning. I Boahult fanns inga trappor att bekämpa. Vi kunde lyssna till

3 Jag lutar mig i det följande till stor del på anteckningar jag gjorde den närmaste tiden efter att min man dött, och vad som fortfarande är och lär förbli ett "manus under arbete". 
tystnaden och bokskogen, le mot sädesärlorna som trippade omkring som om gårdsplan var deras eget revir (man fick stanna upp och vänta tills "de små" flyttade på sig) och mot de visslande trastarna som svarta och majestätiskt trampade omkring på samma gårdsplan, mot rådjuren som kom allt närmare när vi inte orkade klippa gräset och, så småningom, mata våra ekorrungar med solrosfrön.

Men i början fanns ändå hela tiden oron över hur Pauli skulle kunna få läkarhjälp när Universitetssjukhuset i Lund inte låg inom räckhåll. Och mycket riktigt, när hemska host- och andnödsattacker och panikkänslor av det slag som tidigare tvingat oss till Akuten i Lund uppstod, visste vi inte vad vi skulle göra.

Efter ett antal desperata försök att komma igenom telefonväxlar, få tag på någon som visste råd, fick jag slutligen tala med någon vid lungkliniken i Lund som, efter ett studiebesök, råkade (!) känna till att KVH i Hässleholm fanns. KVH står för Kvalificerad Vård i Hemmet.

En sjuksköterska ordnade så att Pauli fick en remiss dit. I början av juni, samma dag som remissen faxats, dök de första KVH-arna upp på gårdsplan i sin lilla röda bil, en läkare och en sjuksköterska. NilsPetter, sjuksköterskan, var den som hade huvudansvar för Pauli, tiden ut. ${ }^{4}$ De stan-

4 De namn jag nämner i denna berättelse är personernas verkliga namn. Jag kan inte förmå mig att använda fingerade namn för människor som var så verkliga för oss. Nuvarande teamchef har bett berörda i personalen läsa detta manus och frågat om det är ok att deras namn nämns. NilsPetter har tillagt att berättelsen stämmer väl med hans upplevelse. nade, tror jag, ett par timmar på en kopp kaffe i trädgårdssoffan, kollade in oss och huset, pratade om möss och musik, presenterade KVH - och förklarade att Pauli var inskriven hos dem nu. När de sa, ring vilken tid på dygnet som helst, vi är här på en halvtimma, så kändes det inte som tomma ord. Det var det inte heller.

$\mathrm{KVH}$ inrymde all kompetens som den medicinska vetenskapen och den beprövade erfarenheten kunde bjuda. Och professionella med olika kompetenser satsade allt de förmådde när andra delar av medicinsk praktik givit upp ambitionen att bota, och därmed konstaterat: "vi kan inget göra".

Det har nog hänt, tyvärr, att läkekonsten i sin ambition att bota, tappat bort de andra uppgifter som Hippokrates, den gamle greken som brukar kallas läkekonstens fader, sägs ha betonat; att lindra och att trösta.

\section{KVH-Kvalificerad Vardi Hemmet}

KVH i Nordöstra Skåne har ett team i Kristianstad och ett i Hässleholm. Boahult tillhör Hässleholms kommun. I ett fåtal av landets kommuner fanns vid denna tid liknande former för hemsjukvård, om än inte lika välutbyggd. ${ }^{5}$

Om Boahult legat några kilometer söde-

5 Enligt en rapport Vård i livets slutskede (Socialstyrelsen 2006) har man efter hand satsat på en utbyggnad av palliativ vård $i$ hemmet och enligt denna inventering kunde någon form av sådan vård då erbjudas i c:a hälften av landets kommuner. 
rut skulle vi ha tillhört Höörs kommun. Då hade vi, liksom om vi bott kvar i Lund, många gånger denna sommar inte haft något annat alternativ än att ringa efter ambulansen eller ta oss till akuten. (Våra tidigare erfarenheter av akuten var hemska och lärde oss: här ska du verkligen inte tro att du är synlig över huvud taget eller att någon har något slags ansvar i den mån du dör på britsen i korridoren.)

Att vara inskriven vid KVH betyder att man i hemmet kan få hjälp med det mesta som ett sjukhus kan erbjuda. Man behöver $t$ ex inte ta sig till apoteket själv för att hämta ut medicin; personalen har den med sig eller rycker snabbt ut för att leverera ny om något skulle ta slut.

De flesta av KVH:s patienter har svåra sjukdomar, oftast cancer, men det kan också vara kronisk hjärt- och lungsjukdom eller neurologiska sjukdomar. Där finns några helt unga patienter men medelåldern ligger nog kring 60. Teamet betjänade, tror jag, ett 50-tal patienter.

Hässleholmsteamet hade på vår tid följande bemanning: 2 läkare, 24 sjuksköterskor (varav två huvudsakligen jobbade natt), 6 undersköterskor samt: sjukgymnast, arbetsterapeut, kurator, dietist och en sekreterare som var den som vanligen svarade i telefon, alltid vänligt, informerat och personligt som om vi kände varandra trots att vi aldrig setts. Därtill fanns tre präster knutna till teamet. (Pauli tog en av sina sista dagar emot den glada, söta i kortkort.)

Eftersom det handlar om avancerad sjukvård så är det naturligtvis viktigt att tyngdpunkten i teamet ligger på ett stort antal kompetenta sjuksköterskor som t ex vid akututryckningar kan göra självständiga bedömningar, ge injektioner osv. Men vad jag vill betona är också hur viktigt det var, åtminstone för oss, att det så självklart dök upp en arbetsterapeut, en kurator, en sjukgymnast. De såg alla sådant som vi inte själva skulle ha kommit på och som mycket påtagligt underlättade livet. Jag tror att - utöver den "rena" sjukvårdspersonalen så blev arbetsterapeuten med sin blick för vilka hjälpmedel som kunde öka just Paulis livskvalitet och självständighet den viktigaste för honom, och kuratorn med sin kompetens och personlighet den viktigaste för mig. Även sjukgymnasten som så självklart gick in i Paulis inställning "jag måste lära mig att andas" fyllde en mycket viktig funktion, även om vi såg honom bara ett par gånger.

\section{Vardagen med $\mathrm{KVH}$}

När jag någon gång undrade hur personalen inte bara kunde orka i detta jobb utan också sprida så mycket glädje i vårt hem, medan döden väntar vid knuten, svarade en undersköterska, Mia: ”Det förstår du väl att det är roligt att komma hit. Det är ju ett hus där kärlek bor."

KVH:arna betonade att de alla själva valt det här sättet att arbeta. Alla som jobbar i KVH har sökt sig dit i stor konkurrens, och genomgått ordentliga anställningsintervjuer. Personalen har inte helt enkelt flyttats ut från någon avdelning på lasarettet för att sköta en billigare vårdform. KVH:arna betonade också det viktiga i att vårdformen verkligen är frivillig, att alla som får denna hjälp själva har valt vård 
i hemmet framför att läggas in på någon institution.

I en mycket anspråkslös broschyr presenterar sig KVH som en sjukvård som kan erbjuda "det mesta som en sjukhusplats kan erbjuda". Jag tycker det är bra med den anspråkslösa framtoningen, utan ideologiska övertoner. Men utifrån mina erfarenheter från den tid då vi så småningom blev allt mer beroende av sjukvården, vill jag påstå att KVH kunde erbjuda vad ingen institutionsbaserad sjukvård kan! Och jag vill då för en gångs skull använda det slitna och urholkade ordet: helhetssyn. Det ordet tror jag tillhör de tommaste ord som finns, när det används av enskilda professionella grupper som ska presentera sitt (unika) synsätt. Men det fick en slags realitet för mig när jag, samlat i Boahult, mötte alla dessa människor med sina olika kompetenser, de som gick runt i huset, kikade och kollade, satte sig på verandan och pratade med Pauli eller oss båda, tog en promenad på "ägorna" med mig - och försynt ställde frågan: tror du att ni skulle ha hjälp av om vi fixade det eller det; en rollator, en rullstol, färdtjänst, klossar under sängen så att ni kan hålla om varandra på nätterna - och sedan: om jag följer med dig till begravningsbyrån?

Vi hade glädje eller nytta av allting, till och med rullstolen den sista kvällen, när Pauli inte orkade ta sig till sängen - den som vi bara lekt med på gårdsplan någon gång under sommaren och sedan gömt undan i Stallet.

Jag skulle vilja ge en detaljerad beskrivning av alla små och stora handlingar för att begripliggöra det förunderliga fenomenet omsorg inom en ytterst professionell ram av kunnighet och kompetens. Basen var naturligtvis det "rent medicinska", de noggranna undersökningarna och täta kontrollerna av om medicineringen var adekvat osv vilket gjorde mycket stor skillnad, jämfört med om man har återbesök var 3:e månad och bara fortsätter med vad som ordinerats ("tills man stupar", som någon av KVH:arna sa). Här får jag nöja mig med några små antydningar om sådant som glimmade till lite extra i vardagen.

- När arbetsterapeuten Jessica fixat dit en sjukhussäng och det visade sig att vi inte kom i jämnhöjd, att dubbelsängskänslan var borta, sa hon: vi måste fixa klossar till din säng och kom tillbaka med sådana, tillsammans med kuratorn Anita. (Var argumentet, att det kunde behövas tre personer för att få dit klossarna, en förevändning för att introducera en kurator?) Det var något fel på klossarna, en bricka till en av dem saknades. Kan vi inte såga till en i vebon, sa någon. Tre damer, Jessica, Anita och jag lyckades såga till en perfekt kloss. Pauli åsåg förundrad hur vi (om än fnittrande) tog snickaruppgiften på så stort allvar, som om den var livsavgörande. Det var den ju. Jag kunde återigen slumra på Paulis arm.

- I slutet av sommaren närmade sig den dag då vi under tidig vår till vänner sagt $\mathrm{OK}$, vi hänger med på bilresa till Lofoten och Hurtigruten för att ombord på båten fira Paulis 60-årsdag. Situationen hade förändrats, mediciner och syrgasapparater av olika slag hade tillkommit, och Pauli sa: fattar Tullia och Sune att de kan få lik i lasten? Det gjorde de nog. Jag undrade hur KVH:arna skulle agera inför att vi gav oss iväg på en sådan resa, när vi nu på hemmaplan under 
ett bra tag, inte klarat oss många dagar utan dem. Tänker de avråda? Nej, stor aktivitet utbröt. Det skrevs ut lätthanterligare, mer långverkande morfin, beställdes syrgastuber som vi skulle kunna hämta ut på järnhandeln i Arvidsjaur före inresan till Norge och sedan nya på hemresan hos Lantmännens $\mathrm{i}$ Strömstad. Nils-Petter kom ut till Boahult med det slags syrgastuber vi behövde för resan. Vi läste gemensamt instruktionerna för monteringen av dem, vilket lät ungefär lika farligt som att desarmera en bomb. Vi beslöt oss för att de som skrivit instruktionerna säkert överdrivit, men att det nog ändå är bäst att göra det utomhus. Andra från $\mathrm{KVH}$ ringde de sista dagarna före avfärd, frågade om vi hade allt vi behövde, det är så vackert där uppe, ring oss för allt $\mathrm{i}$ världen om det krånglar. Jag hade tänkt: bör jag före resan ta reda på vad jag ska göra om Pauli dör. Men uppfattade (utan att ställa frågan) deras budskap: ring oss i så fall. Jag ringde ett par gånger från Norge, när vi trodde "nu är det färdigt". Det fanns även mitt i natten en läkare som sa: gör si och så. Vi kom lyckliga (i ordets verkliga mening) hem och hade några få veckor kvar.

- Under de veckorna inföll vår 28:e bröllopsdag, vi hade nämligen firat den 17:e varje månad sedan vi gifte oss 17 maj. Vilket innebar att vi redan, i vår världsbild, hunnit med silverbröllop. Jag hade bestämt mig för att plantera ett träd på gården den dagen. Det var september, och vi hade ganska exakt 10 dagar kvar. Nils-Petter var där. Lyssnade på Paulis lungor och svarade rakt och uppriktigt på Paulis frågor. "Framtiden" sa Pauli, när han menade: hur blir det när jag dör, kommer jag att kunna behålla min värdighet? I journalanteckningarna från den dagen har Nils-Petter skrivit "givande samtal och trädgårdsarbete". Hans pappa hade varit trädgårdsmästare, han engagerade sig i trädplanteringen och rådde mig att jag skulle lägga den lite finare jorden överst, i den där gropen i den hårda jorden, som jag inte fattar att jag orkade gräva.

\section{Tre i rummet}

Under sina sista veckor på jorden sa Pauli: Det är konstigt, när jag vet att det är bara du och jag här i rummet så tycker jag ofta att vi är tre personer här: jag Pauli, du Rosmari och Vi. Så när du Rosmari lämnar rummet en stund tycker jag ändå att du är kvar.

Den formuleringen hjälpte mig sedan att förstå varför jag inte grät så mycket och inte kände mig riktigt ensam under de två veckor jag fysiskt sett var alldeles ensam kvar i skogen, i höstmörkret, och såpskurade huset inför den minnestund som jag inte kunde tänka mig någon annanstans än där, i Boahult.

Men formuleringen "tre i rummet" påminner mig också om att det, under den allra första tiden efter att vi fått veta att Pauli snart måste dö, stundtals fanns bara två ensamma och stumma "jag" i rummet - och en tredje objuden gäst, vid namn Döden.

Under vår sista tid tillsammans fanns där ofta en annan tredje person i rummet, någon från $\mathrm{KVH}$ (en Ulla, en Liselott eller en Mia, en Nils-Petter, Carina, Marie, Gunnel eller Cecilia) som jag tyckte "flöt in" i vårt Vi. Jag tror att även Pauli upplevde det så när han, jag och sjuksköterskan Ulla 
satt i rummet den sista eftermiddagen och Pauli sa: det är bra att det är vi tre som sitter här i rummet.

Paulis sista handling blev att lägga sin hand på mitt lår. Efter att jag, som jag lovat, lyckats le mot Pauli - inte gråta-den korta stund under Paulis sista timme på jorden då hans ögon, åter, blev stjärneklara. Paulis luriga leende kom tillbaka då och stannade kvar.

Sjuksköterskan Ulla, som suttit där i rummet, som en ängel, hela tiden, tittade stilla på sitt armbandsur, noterade tiden för Paulis sista andetag: kl 23.30 den 26 september, 1998. (Jag tror Ulla sa "halv tolv".)

Två veckor senare dök oväntat samma läkare som i början av sommaren kommit i den första röda bilen från KVH, Lars-Erik, i sin blå täckjacka upp på gårdsplanen. Han arbetade inte längre på KVH, men hade sett dödsannonsen och kom till minnesstunden i Boahult. Jag sa: "men ni har ju den principen att inte gå på era patienters begravningar”. Han sa väl ungefär bara: principer och principer. Och tillade: "Rosmari, om någon nu kommer och säger plattityder som 'att tiden läker alla sår' eller något, så slå inte ner dem. Gå bara undan."

När kistan (där i salen) öppnades var det denne läkare som höll mig i handen. Han tog den bokkvist som jag, tafatt, ville lägga i kistan hos den då alldeles granitkalla Pauli ur min hand och satte den i Paulis.

\section{Respekten för det individuella}

För många år sedan läste jag, eftersom bokens titel fascinerade mig, Peter Nolls Den utmätta tiden. Nu när vi fått besked om Paulis - och vår gemensamma - utmätta tid, läste jag om denna bok. Under 9 månader, efter att den schweiziske juristen Peter Noll hade fått besked om att han hade cancer och avböjt behandling, dikterade han sina tankar om makt och rätt och om döendet och döden. Han beskriver denna tid som "fylld av en hel del sorgsenhet, men också äkta munterhet och, förvånansvärt nog, ingen som helst förtvivlan”. I ett vackert förord till den svenska upplagan av boken, skriver Georg Klein (1985) om hur Peter Noll såg på döden.

Han reagerade starkt mot det 'serietillverkade' döendet i våra dagar. Man dör på löpande band, det blir allt banalare, den individuella döden har avskaffats som onödig lyx. Döden är inte längre något tema; den har skilts från livet och förvisats till sjukhus och ålderdomshem. Detta gjordes $i$ förhoppningen att de överlevande kommer att bli lyckligare om de slipper att ständigt konfronteras med döden. Det blev de kanske på sätt och vis, men man har samtidigt gått miste om något väsentligt. Man har egentligen bara uppnaitt ett slags bekvämlighetsinrättning, ett hjälpmedel som hör hemma under samma rubrik som disk-och tvättmaskiner. (a a, s. 11.)

Vi hade lyckan att få erfara "lyxen" av en gammeldags död - eller var det en postmodern? I vart fall blev det ett döende och en död där det inte ett ögonblick brast i de professionellas respekt för individen och det individuella. Jag lånar ett citat från Pauli, där han formulerade saken så här:

I vårdapparaten kan det individuella inte 
finnas förrän det erkänns som berättigat. $\mathrm{Om}$ det individuella inte är legitimt finns det bara som en avvikelse, som något som stör, som ett problem för organisationen. (Lappalainen 1995, s. 92)

För KVH:arna tycktes "det individuella" inte vara något störningsmoment. Även i något annat sammanhang stötte vi $i$ vårdapparaten på enskilda människor som stod för en gyllene förening av professionalitet och ömsint omsorg. Men i KVH var det som en grundbult. Hur kunde alla i den organisationen klara detta svåra att följa sina patienter in i döden, med hela sin arsenal av hjälpmedel, utan att tappa vare sig sitt varma leende eller sin entusiasm? Jag kan naturligtvis inte fullt ut besvara "varför-frågan", men vet att det är möjligt. En av nycklarna till gåtan tror jag ligger $i$ att man i denna verksamhet fått ihop organiseringen av arbetet utifrån respekt för människor och deras individualitet. Både sina anställdas och sina patienters.

\section{Omsorgens väsen}

Det finns en retorik som talar om patienters rätt till autonomi (med synonymer som självständighet och oberoende). Vad jag vill betona är vikten av att också personalens individualitet, självständighet och förmåga att ta personligt ansvar i situationen respekteras.

I en situation som $t$ ex Paulis krymper ju obevekligen graden av autonomi i betydelsen oberoende. Vad man - för att inte hamna i en ständig aggressivitet mot situationen - måste lära sig acceptera och leva med är ju just ett ökat beroende av andra. För den skull ska man inte behöva berövas respekten för sin individualitet; sin egen vilja, sina egna önskningar, vanor och ovanor.

Ser vi till KVH:arna så uppfattade jag det så att de i hög grad förväntades handla utifrån personligt omdöme, men att de för den skull inte stod där helt "autonoma" i betydelsen helt självbestämmande och icke beroende av andra människor. KVH:arna hade alltid sin mobiltelefon till hands, de kunde ringa och rådgöra med någon kollega - och de hade sina konferenser där hela teamet diskuterade sina "fall".

Vad jag vill ha sagt är väl helt enkelt vad som länge framstått som en sanning för mig: att vi som människor - antingen vi är vårdgivare eller vårdmottagare, maka/make, förälder eller barn osv - så är vi både beroende av andra människor (och av våra omvärldsbetingelser) och (vanligen, men inte alltid) vill vi agera som självbestämmande individer och har rätt att bli betraktade som sådana. Det handlar inte om antingen/eller, utan både/och. Den där svåra balansgången mellan "vårt ansvar för varandra" och "respekten för den enskilda människan" är något som jag ser som en kärna $\mathrm{i}$ "omsorgens väsen" och som jag skrivit om i olika sammanhang (bl a i Eliasson 1987/1995, s 58 ff). Den hjälp vi fick från KVH materialiserade konsten att klara den balansgången. Nästa avsnitt är ett försök att fortsätta söka svar på frågan: vad gör det möjligt?

\section{En röst från $\mathrm{KVH}$}

Det fanns en del frågor som jag efteråt 
tänkte att jag borde ställa till KVH-personalen, men jag var inte företagsam nog att ringa upp för någon form av intervju. När snart ett år gått efter att Pauli dog ringde telefonen en kväll. "Hej, det är Nils-Petter, jag undrade om du var i Boahult. Har du något emot att jag tittar in en stund, jag har ett par lugna timmar."

Det första jag tänkte var: Pauli skulle sagt att då får du sätta på kaffe. Jag satte på kaffe. Jag vet ju att de tar sig snabbt fram KVH:arna, på skogsvägarna, och snyggade till lite i köket medan jag försökte minnas vad det var jag ville fråga om. Men nu som då blev min känsla att stunden är viktigare än frågorna och jag ville hellre smaka på känslan "vad gott att du dyker upp, grabben" än tänka ut några intervjufrågor.

När den röda bilen svänger in på gårdsplan vill jag gråta, Nils-Petter ser det och säger att han tänkt på det på vägen hit: hur kommer det att kännas för Rosmari när hon ser KVH-bilen? Jag tror jag lyckas visa att tårarna bakom ögonlocken betyder glädje i igenkännandet; inget känns så välbekant som den där kommunala bilen. Jag använde (utan att närmare tänka på ordets betydelse) ordet "nostalgiska" känslor för att förklara att det kändes gott och bra att se den röda bilen.

Ett par dagar senare ägnar Karin Johannisson, idé och lärdomshistoriker, sitt sommarprogram i Pl åt begreppet nostalgi. Ordet nostalgi står för hemlängtan, förtärande hemlängtan. Det "hemma" vi längtar efter kan bestå både av arkadiska ängar och nattsvarta helveten. När jag hört det där sommarprogrammet på temat nostalgi, tyckte jag att jag valt rätt ord för att tala om för Nils-Petter att mina tårar var varma.
(Senare har jag snappat upp en enklare definition av begreppet nostalgi, sagt av någon isländsk författare: "to be glad to be sad".)

Nils-Petter tittade sig omkring i huset och sa att här är sig likt. Jag sa: allt och inget är sig likt här i Boahult. Bara i sovrummet (där dubbelsängen halverats till en smal liten bädd) är skillnaden synlig. Det kändes som en högtid när Nils-Petter stod tyst där inne en lång stund. Jag sa att rådjuren och hararna inte har rört Trädet, det har vuxit. Nils-Petter sa: "jag såg det, blev glad."

Så satt vi på verandan igen, jag noterade att det var trångt för Nils-Petters långa ben och kände igen hans sätt att hantera den situationen. Jag sa att jag har bryggt kaffe, och Nils-Petter replikerade: gjorde inte du det så gjorde Pauli det. Jag vet att vi tänkte på samma episod under sensommaren. Jag hade vid ett tillfälle struntat i det där med att sätta på kaffe, Pauli hade varit i riktigt dåligt skick och jag tänkte väl att det inte var så viktigt med kaffe. Men det tyckte Pauli, och ingen av oss ingrep när Pauli med oerhörd möda tog sig upp ur stolen på verandan och gick in i köket och satte på kaffe. Vi satt här nu på verandan, NilsPetter och jag, och bara mindes en stund, innan jag ställde en fråga som legat högt i mitt medvetande: Hur orkar ni i KVH med detta att satsa så mycket kraft på människor som alla, åtminstone nästan alla, kommer att dö i era händer? Nils-Petter sa att jag kan ju bara svara för mig själv, och svaret kom snabbt:

Jag har hållit liv i så många, till varje pris, att jag började uppleva det som absurt. De flesta av våra patienter nu har accepterat detta att de ska dö, deras anhöriga har gjort det och vi har gjort det. Att hjälpa dem 
att få en dräglig tid och ett bra slut upplever jag som mer meningsfullt och mindre påfrestande än att arbeta på sjukhus. Och så är det ju detta att vi har roligt tillsammans i teamet, och framför allt att vi kan arbeta självständigt. Vi har en administrativ chef, en distriktssjuksköterska som begriper det mesta, utan att nödvändigtvis ha varit hemma hos patienten och två erfarna läkare. De ger oss fria händer när det handlar om sådant som smärtstillande. På sjukhuset var det så att det ofta var ATläkare som jobbade, vi var som sjuksköterskor tvungna att fråga dem, trots att vi visste att vi visste bättre själva. Man vågade t ex inte avstå från att sätta in livsuppehållande insatser, fick inte låta någon dö så stilla och rofyllt som möjligt.

När Nils-Petter övertygat pratar om det meningsfulla i detta att hjälpa människor att få dö lugnt och att allt ska vara så fint som möjligt minns jag att min första känsla den natt Pauli dött faktiskt var tacksamhet: vi fann varandra och vi har klarat både Livet och Döden, vi har klarat oss fram till mållinjen. Vi hade förmått säga till "herr Döden": stig på, du är väntad.

Nils-Petter menar att en viktig förutsättning för att vi ska dö utan ångest är att vi accepterat detta faktum. Vi pratar om att allt tydde på att Pauli gjort så, och att han nog visste på kvällen att det var hans sista. Jag berättar om att Pauli ordinerade sig själv Stesolid den kvällen (och att Ulla nickade: ok). Nils-Petter skrattar gott, säger att Stesolid var ju inte annars Paulis melodi, inte till vardags. Han tror att det ofta är så att man vet och vill komma till ro.

När jag frågar om hur de flesta dör, om de flesta får dö lugnt och stilla som Pauli, säger Nils-Petter att det nog är det vanliga, men kanske en på tio drabbas av dödsångest. Jag frågar om hur dödsångesten kan yttra sig och om det är det vi talar om som dödskamp. Jo, säger Nils-Petter, det är så dödsångesten ofta yttrar sig, i att man kämpar emot, vägrar sluta andas. Det blir tuffare för oss då, men framför allt svårare för anhöriga. Det kan vara mycket svårt, det svåraste också för oss. Nils-Petter beskrev en nyligen inträffad sådan situation för mig och frågade flera gånger: orkar du höra? Efter sådant, sa Nils-Petter, så behövs det extra lång tid att ladda batterierna.

Jag frågar vad det kan vara som gör att man inte orkar i det här jobbet. Nils-Petter säger att det är nog olika, men att det han själv är mest rädd för är saknaden när någon är död. Man måste ju försöka hålla lite distans, tänka att Pauli inte är min släkting - men han blev ju en vän. Nils-Petter kommer in på det där med att komma till begravningen eller ej. Han menar att vi nog skulle behöva det för vår egen skull ibland; att det avskedet kan vara lika viktigt för oss i vården som för andra som stått den döde nära. Likaså kan man önska att man fått vara med när någon dör. Jag säger att jag först efteråt insett att Ulla, som var hos oss när Pauli dog, faktiskt aldrig varit här tidigare, men att för oss tror jag inte det spelade någon roll, hon smalt ju ändå ihop med oss och huset. Nils-Petter tycker att det är ju skönt att höra, eftersom detta är ett problem som inte kan lösas. Pauli dog ju på natten, som de flesta, och dessutom en helg. Men likafullt kan han önska för sin egen skull att han varit där och hos andra som han lärt känna.

Så kommer jag ihåg att en bekant sagt 
att alla som jobbar på KVH väl måste ha fått någon speciell utbildning inför detta att arbeta i hemmet med döende patienter. Jag sa att jag knappast tror det, men jag ska fråga. Nils-Petter sa att det är klart att vi åker på en del kurser och konferenser, men vi har ingen särskild utbildning, och jag ser det som en fördel. Vi har inte en gemensam uniform utan tar lite av varje. Själv är jag narkossköterska, och det har jag nytta av när någon har det så svårt inför döden att vi måste söva ner. Andra bland sjuksköterskorna är distriktssköterskor och någon $\mathrm{t}$ ex långvårdssjuksköterska, vi har olika erfarenheter. Det har varit samma bland läkarna, någon har varit lungspecialist andra allmänläkare, undersköterskorna har också olika bakgrund och så har vi ju de andra kompetenserna, kurator, arbetsterapeut, sjukgymnast, prästerna; alla har med sig sitt. Jag fällde någon kommentar om $\mathrm{KVH}$ :s lilla broschyr och att där inte står något sådant som "gemensam människosyn" eller andra ideologiska deklarationer (som brukar förekomma när pionjärverksamheter presenterar sig). Nils-Petter sa att det är nog lite medvetet, var och en har sin människosyn och jag är ju ingen organisation. Jag uppfattar vad Nils-Petter säger som: det är ju jag som kommer hem till patienten för att göra vad jag kan, inte en institution eller organisation.

I något sammanhang, när jag läst en del modern filosofi, har jag inte kunnat låta bli att associera KVH-arnas sätt att vara och resonera till ett "postmodernt förhållningssätt": en ny respekt för det individuella och en bristande foglighet inför uppifrån givna normer och anvisningar för hur en människa bör vara och bete sig. Men det behö- ver ju inte handla om något nytt sätt att vara, utan om ett evigt - i den mån människor får handlingsutrymme nog. Sociologen Zygmunt Bauman (1989) har beskrivit den hållning jag ser hos KVH-arna som ett moraliskt ansvar; att man tar personligt ansvar för den andres välbefinnande. Detta till skillnad från ett tekniskt ansvar, då man fullgör sin uppgift genom att följa regler och principer. Eller manualer, kanske.

När jag med Nils-Petter tar upp min undran över hur de på KVH kan lyckas arbeta med en sådan flexibilitet att ingenting någonsin tycks vara i vägen när man behöver dem hänvisar Nils-Petter igen till självständigheten: vi lägger ju upp arbetet själva tillsammans med patienten. Det är $t$ ex ingen som har ont av att jag åker hit ut till dig nu en stund innan jag ger antibiotika till min sista patient i kväll. Det finns inget schema, bara ett arbetsschema på när vi jobbar, hur dags vi börjar och slutar. Vi har en ganska kort rond på morgon, lite längre före och efter en helg och en gång i veckan en "social rond" där inga medicinska frågor får tas upp och där alla deltar: kurator, arbetsterapeut, sjukgymnast, dietist och präster. Men sin dag lägger man upp själv. Om Pauli behövde hjälp snabbt så kunde vi ringa till någon patient där det inte var akut och fråga om det gick bra att vi kom senare på dagen. Eller ordna så att någon annan, ibland någon från ett annat team, åkte över med mediciner om det var det som behövdes.

Jag minns ju att det några gånger kom bilar i annan färg än röd till oss, d.v.s. team som hade ansvar för andra områden i trakten. Som patient (nå: patient och "anhörig') tyckte vi bara: oj, vad bra att medicinen 
kom så snabbt och reflekterade inte över detta att bilen inte var röd kunde betyda att någon av "våra" KVH:ares andra patienter kanske låg för döden.

När Nils-Petter berättade om självständigheten; det om att få använda sitt eget omdöme, vara den person man är, slippa skoluniform och ha "var och en sin människosyn", använda sina olika erfarenheter och kompetenser - och om den risk man tar att känna saknad, när man vågar engagera sig personligt - så tycker jag nog att jag började förstå varför vi upplevde den hjälp vi fick av KVH som en "gåva". Då i upplevelsen frågade jag ju inte så mycket; fanns bara, tackade och tog emot.

Efter några koppar kaffe på verandan, när kvällssolen lagt sig, tyckte jag att jag fått svar på några av de frågor som jag burit på och tyckt att jag (som forskar om vård och omsorg) måste söka svar på. Nils-Petter visade, som vanligt, inga tecken på brådska och vi återgick till att minnas episoder vi kunde le eller skratta åt. Vi hade en gemensam minnesbild av den dagen då jag planterade Trädet som den första gången Pauli tog upp frågan om "framtiden". Vi mindes båda att Nils-Petter svarat som om frågan varit uttalad: hur kan det bli när jag dör?

Vi pratade inte så särskilt mycket om döden, Pauli och jag, utom i den första förälskelsen och möjligen de första veckorna efter Beskedet. Jag sa att Pauli nog inte undrade just över vad kanske några gör: vad som kommer efter. Vi försökte ju fånga dagen, varje dag, och jag tror nog fan att Pauli visste att när man är död så är man. Nils-Petter skrattade igen, och sa: det tror jag nog.

Jag kom in på berättelser om det sista dygnet och sa att det fanns förväntningar från något av Paulis barn att han skulle säga "några sista ord". Jag sa att det är möjligt att Paulis stora önskan var just att ha några sista ord att säga. Men du vet ju hur noga Pauli var med formuleringarna, hellre teg han än kom med en dålig formulering. Det verkade vara just detta Nils-Petter fäst sig mest vid hos Pauli, eftertänksamheten och precisionen i formuleringarna. Han sa att jag aldrig har mött någon som Pauli, någon som så mätte orden på vågskål, man borde lärt sig av honom. På det svarade jag ungefär: och nu sitter du här på verandan med Paulis motpol, i det avseendet. Det går ju rätt bra det också. Vi skrattade igenkännande åt detta också: man är ju olika.

Min sista fråga till Nils-Petter, innan han åkte iväg till sin sista patient för kvällen blev: då när Paulis ögon blev alldeles klara någon gång under den sista timmen, då när han la sin hand på mitt lår och leendet kom, tror du han såg mitt leende då, tro du att Pauli var "klar" och "vid medvetande" då? Det är jag fullständigt övertygad om, sa Nils-Petter.

Han hjälpte mig bära in en vedkorg från ladan och sa på vägen: Den sista som dog ifrån oss var en ganska ung kvinna, hon bad om en cigarett 20 minuter innan hon dog.

Jag tänkte, hoppas det finns någon som tänder den där sista cigaretten åt mig. Och vinkade, som vanligt, när den röda bilen for neråt vägen.

PS. I september månad varje år, går vår sista tid som en film i mitt huvud. NilsPetter vet det och har under 10 års tid sänt mig ett brev varje september. Berättat lite om vad han och hans son gjort, och sådant. 


\section{Slutkommentar och några frågor}

De olika uttryck för omsorg som Pauli och jag fick del av är det nog svårt att finna s.k. evidens för med (i vissa sammanhang) gängse forskningsmetoder. Men vi borde, utan randomiserade kontrollerade experiment och korrelationskoefficienter, kunna begripa förtjänsterna med en vårdform och ett sätt att organisera den - som möjliggör den slags mänsklighet av bästa sort som vi fick erfara.

Jag vet att många vård-, omsorgs- och socialarbetare i sitt personliga engagemang gör liknande saker som KVH-arna. Men sådant kommer knappast med i standardiserade utvärderingar eller i sökandet efter evidensbaserade metoder. Jag är rädd att många t o m undviker att "rapportera" sådana (livsviktiga) handlingar - på grund av att de löper risk att betraktas som "oprofessionella". Min berättelse handlar om en ytterst professionell vård, tillräckligt trygg i sin uppgift för att låta kärleken, livet och döden, glädjen och sorgen samsas i "samma paket".

Vi har i vår forskning om "vanlig" äldreomsorg sett samma sorts kompetens ta sig uttryck i praktiken, även om den där ofta fått smyga sig till det i strid mot där härskande principer.

Till det jag undrat över är att det tycks finnas stort motstånd, bl a från den sjukhusbaserade vården, mot uppbyggnad av liknande former för vård $\mathrm{i}$ hemmet som KVH erbjuder. Konstigt att det finns bromsklossar för en vård i livets slutskede som enligt många utsagor är både "billigare och bättre" ${ }^{6}$ Kan det handla om ideologi mer än ekonomi? Möjligen om värnade av ekonomiska resurser för det slags palliativ vård som begränsar sig till experimenterande med olika medicinska behandlingar? (En del av "de falska förhoppningarnas kemoterapi" är nog inte riktigt etiskt försvarbara utifrån devisen att "inte skada" och borde kanske betalas av läkemedelsindustrin snarare än av skattemedel?) Kan det handla om ovilja att erkänna att "allting inte går att bota"? Eller om ett värnande om stereotypa föreställningar om hur modern, vetenskapsbaserad sjukvård ska se ut: Om det nu är så att patienten och dennes anhöriga verkligen önskar få hjälp i hemmet så ska de väl ändå inte vänta sig möjligheten att få en medicinsk hjälp av lika hög kvalitet som den som kan erbjudas inom etablerade institutioner och mer beprövade modeller. Jag hoppas innerligt att det inte finns en underliggande, snål tankestruktur som säger: när du är ute av banan och inte längre reparerbar - döende av obotbar sjukdom eller bara gammal och skröplig - så ska du väl inte vänta dig en vård som bjuder till allt den förmår.

En annan snålhet är naturligtvis den som faktiskt räknar i pengar och som leder till att åldrande och/eller dödssjuka människor

6 Rimligtvis måste vård $\mathrm{i}$ hemmet vara kostnadsbesparande för samhället, eftersom den $\mathrm{i}$ hög grad vilar på anhörigas insatser. Det finns beräkningar som säger att vård i livets slutskede är dubbelt så dyrt vid Hospice, jämfört med vård $\mathrm{i}$ hemmet, och upp till 5 gånger dyrare vid sjukhus. Jag har inte hittat några svenska jämförelser av kostnader som verkar tillförlitliga, men ett par engelska rapporter, $t$ ex Hatziandreu $\mathrm{m} \mathrm{fl}(2008)$. 
inte, hur mycket de (och deras anhöriga) än så önskar, kan få komma till ett särskilt boende, hospice eller sjukhus. Kanske erbjuds de en "sjukvård i hemmet" som består av att två distriktssjuksköterskor har ansvar för ett alldeles orimligt stort antal patienter.

Alltså: med min berättelse vill jag inte plädera för vård i hemmet som en generell lösning, och definitivt inte anföra ekonomiska argument för den vårdformen. Sådana argument kan missbrukas. Vad jag vill visa är att det går att förena en vetenskapsbaserad professionell kompetens med mänskligt engagemang och det vi kallar omsorg.

\section{Referenser}

Anttonen, Anneli (1998) Den sociala servicestaten som feministiskt kampbegrepp. I R EliassonLappalainen \& M Szebehely (red.) Vad förgår och vad består. Lund: Arkiv.

Bauman, Zygmunt (1989) Auschwitz och det moderna samhället. Göteborg: Daidalos.

Braverman, Harry (1977) Arbete och monopolkapital (eng. orig 1974). Stockholm: Rabén \& Sjögren.

Einhorn, Jerzy (1998) Det är människor det handlar om. Stockholm: Albert Bonniers Förlag.

Eliasson, Rosmari (1987/1995) Forskningsetik och perspektivval. Lund: Studentlitteratur.

Eliasson, Rosmari (red.) (1992) Egenheter och allmänheter. En antologi om omsorg och omsorgens villkor. Lund: Arkiv.

Eliasson, Rosmari (red.) (1996) Omsorgens skiftningar. Begreppet, vardagen, politiken, forskningen. Lund: Studentlitteratur.

Eliasson-Lappalainen, Rosmari (2007) När blev det normalt att vara kvinna - i akademin och teorin? I K Svensson (red.) Normer och normalitet $i$ socialt arbete. Lund: Studentlitteratur.

Eliasson-Lappalainen, Rosmari \& Szebehely, Marta (red.) (1998) Vad förgår och vad består? En antologi om äldreomsorg, kvinnosyn och socialpolitik. Lund: Arkiv.

Eliasson-Lappalainen, Rosmari \& Szebehely, Marta (1999) Care for the Elderly: Conditions and Everyday Realities. Comparative perspectives on Scandinavian welfare states, welfare muni- cipalities and the patterns of care from the view of elderly persons. (Forskningsprogram) www. soch.lu.se/o.o.i.s/25284

Eliasson-Lappalainen, Rosmari \& Szebehely, Marta (2008) Vardagslivsforskning. I A Meeuwisse, $\mathrm{H}$ Swärd, R Eliasson \& K Jacobsson (red.) Forskningsmetodik för socialvetare. Stockholm: Natur \& Kultur.

Eliasson-Lappalainen, Rosmari, Wærness, Kari \& Tedre, Silva (2005) Perspektiv i forskning om äldreomsorg. Personliga tillbakablickar samt trender i akademiska avhandlingar 1995-2004. I M Szebehely (red.) Äldreomsorgsforskning $i$ Norden. En kunskapsöversikt. TemaNord 2005:5008. Nordiska ministerrådet, Köpenhamn.

Hatziandreu, Evi, Archontakis, Fragiskos \& Daly, Andrew (2008) The potential cost savings of greater use of home- and hospicebased end of life care in England. Rapport för National Audit Office (NAO), Cambridge: Rand.

Klein, George (1985) Förord i Peter Noll: Den utmätta tiden. Stockholm: Brombergs förlag.

Lappalainen, Pauli (1995) Vägen över Lyckebo. Meddelanden från Socialhögskolan 1995:3, Lunds universitet.

Leira, Arnlaug (1992) Welfare States and Working Mothers. Cambridge: Cambridge University Press.

Socialstyrelsen (2006) Vård i livets slutskede. Socialstyrelsens bedömning av utvecklingen i lands- 
ting och kommuner. Artikelnr 2006-103-8, ISBN 91-85482-84-6.

Szebehely, Marta (1995) Vardagens organisering. Om vårdbiträden och gamla $i$ hemtjänsten (akad avh) Lund: Arkiv.

Szebehely, Marta (red.) (2003) Hemhjälp i Norden - illustrationer och reflexioner. Lund: Studentlitteratur.

Szebehely, Marta, red. (2005) Äldreomsorgsforskning i Norden. En kunskapsöversikt. TemaNord 2005:5008. Nordiska ministerrådet, Köpenhamn.

Vabø, Mia (2004) Effektivitet og kvalitet i omsorgstjensten - en dragkamp mellom nye og gamle styrningsidealer. I R Dahle \& K Thorsen (red.) Velferdstjenster $i$ endring. Når politikk blir praksis. Oslo: Fagboksforlaget.
Widerberg, Karin (1981) Marxismen som en del av det patriarkala arvet - ett feministiskt perspektiv på kapitalismen. Sociologisk Forskning. Vol 18, nr 2, ss. 3-11.

Wærness, Kari (1980) Omsorg som lönearbete - en begreppsdiskussion. Kvinnovetenskaplig Tidskrift, Vol 1, nr 3, ss. 6-17.

Wærness, Kari (1982) Kvinneperspektiv på sosialpolitikken. Oslo: Universitetsforlaget. Svensk utgåva 1983: Kvinnor och omsorgsarbete. Stockholm: Prisma.

Wærness, Kari (1984) The Rationality of Caring. I M Söder (red.) Economic and Industrial Democracy, Vol 5, No 2, London: Sage Publications, ss. 185-211. 